\title{
Presence of Naraoia Walcott, 1912 (Nektaspida, Arthropoda) in the middle Cambrian of Europe (Murero, NE Spain)
}

\author{
Rodolfo GOZALO ${ }^{*}, M^{a}$ Eugenia DIES ÁLVAREZ², José Antonio GÁMEZ VINTANED', \\ Juan B. CHIRIVELLA ${ }^{4}$ \& Eladio LIÑÁN ${ }^{5}$
}

${ }^{1}$ Departamento de Botánica y Geología, Universitat de València, c/ Dr. Moliner 50, 46100- Burjassot, Spain; rodolfo.gozalo@uv.es

${ }^{2}$ Departamento de Didáctica de las Ciencias Experimentales-IUCA, Universidad de Zaragoza, c/ Valentín Carderera 4, 22003-Huesca, Spain; medies@unizar.es

${ }^{3}$ Department of Geosciences, Faculty of Sciences \& Information Technology, Universiti Teknologi PETRONAS (UTP), 32610

Bandar Seri Iskandar (Tronoh), Perak Darul Ridzuan, Malaysia; jose.gamez@utp.edu.my

${ }^{4}$ Departamento de Ciencias de la Educación, Universidad CEU Cardenal Herrera. Avda. Seminario s/n, 46113 Moncada, Spain; juamar@iesorriols.com

${ }^{5}$ Departamento de Ciencias de la Tierra-IUCA. Universidad de Zaragoza, 50009 Zaragoza, Spain; linan@unizar.es

* Corresponding author

Gozalo, R., Dies Álvarez, Ma.E., Gámez Vintaned, J.A., Chirivella \& Liñán, E. 2018. Presence of Naraoia Walcott, 1912 (Nektaspida, Arthropoda) in the middle Cambrian of Europe (Murero, NE Spain). [Presencia de Naraoia Walcott, 1912 (Nektaspida, Arthropoda) en el Cámbrico medio de Europa (Murero, NE de España)]. Spanish Journal of Palaeontology, 33 (1), 83-88.

\section{ABSTRACT}

The genus Naraoia Walcott, 1912, a Burgess Shale-type fossil known from the lower and middle Cambrian of British Columbia (Canada), Idaho and Utah (USA), as well as from Yunnan and Guizhou provinces (China), is now reported from the middle Cambrian of Murero (Zaragoza, Spain), which is the first record in the Acadobaltic province. The only fragmented specimen found is determined as Naraoia sp., its age being Pardailhania multispinosa Zone (Drumian Stage). This new datum reinforces the hypothesis of the existence of a cosmopolitan faunal substrate in early Cambrian times, which is to some extent reflected in the mid Cambrian by faunal groups of low evolutionary potential as the family Naraoiidae and other soft-bodied fossil taxa.

Keywords: Systematics, Arthropoda, Drumian (Cambrian Series 3), palaeobiogeography.

\section{RESUMEN}

El género Naraoia Walcott, 1912, es un fósil de tipo Burgess Shale, conocido en el Cámbrico inferior y medio de la Columbia Británica (Canadá), Idaho y Utah (EE.UU.), así como en las provincias chinas de Yunnan y Guizhou. Este hallazgo en Murero (Zaragoza, España) supone el primer registro del género en la provincia Acadobáltica. Sólo se ha encontrado un espécimen fragmentado que se ha determinado como Naraoia sp., en la Zona de Pardailhania multispinosa (Piso Drumiense). Este nuevo dato refuerza la hipótesis de la existencia de faunas cosmopolitas durante el Cámbrico temprano, que se extenderían hasta el Cámbrico medio en algunos grupos faunísticos con baja tasa evolutiva, como es el caso de la familia Naraoiidae y otros taxones fósiles de organismos de cuerpo blando.

Palabras clave: Sistemática, Arthropoda, Drumiense (Serie 3 del Cámbrico), paleobioegografía. 


\section{INTRODUCTION}

The Family Naraoiidae is an arthropod group represented by commonly non-mineralized taxa. They are abundant and well preserved in the Burgess Shale (British Columbia, NW Canada) and Chengjiang (Yunnan, S China) Lagerstätten (Whittington, 1977; Hou et al., 2004; Zhang et al., 2007). They have also been found in the lower and middle Cambrian of Idaho and Utah (western USA) (Robison, 1984) and in the Kaili and Balang faunas in Guizhou (S China) (Zhao et al., 2005; Peng et al., 2012). Herein, we describe the first non-calcified nektaspid arthropods found in Murero (Spain), which is also the first record of the family Naraoiidae in Europe, as well as in the Acadobaltic province (sensu Sdzuy, 1972; Sdzuy et al., 1999).

The lower and middle Cambrian Murero Lagerstätte is a $195 \mathrm{~m}$-thick, marine monofacial stratigraphic succession, deposited in a sublittoral environment under a subtropical climate. It has yielded arthropods, represented by more than 80 trilobite species (Liñán \& Gozalo, 1986; Liñán et al., 1996, 2008) and some bradoriids (Gozalo et al., 2004), up to 6 species of brachiopods (Liñán \& Mergl, 2001), up to 15 taxa of echinoderms, including eocrinoids, edrioasteroids, and cinctans (Zamora, 2011), and hyoliths. Burgess Shaletype fossils include clorophytic and phaeophytic algae (Liñán et al., 2012), sponges (García-Bellido et al., 2007, 2011), palaeoscolecid ecdysozoans (Conway Morris \& Robison, 1986; Gámez Vintaned, 1995; Zhuravlev et al.,
2011) and xenusian lobopods (Gámez Vintaned et al., 2011). Twenty ichnotaxa have been described in Murero (Gámez Vintaned \& Mayoral, 1992, 1995). Thus, the Cambrian site of Murero represents an exceptional geological site in order to research the global events affecting the planet during the early-mid Cambrian transition and mid Cambrian times (recorded in rocks of the Cambrian Series 2 and 3).

\section{GEOLOGICALAND STRATIGRAPHICAL SETTINGS}

The village of Murero is located by the Jiloca river, near the historic city of Daroca, $80 \mathrm{~km}$ southwards from Zaragoza (Aragón, NE Spain). Murero is framed in the Western Iberian Chain (Badules Unit), in the heart of the Iberian Mountains (Fig. 1). The fossiliferous strata near Murero are located in the Villafeliche block (Gozalo et al., 1993), cropping out in a normal succession dipping SW and being affected by normal faults. The Cambrian strata are exposed to the north of Murero along the rambla de Valdemiedes (Valdemiedes gully). Among the several stratigraphic sections studied, the rambla de Valdemiedes 1 section (RV1) is located on the right bank of the gully (Liñán \& Gozalo, 1986; Liñán et al., 2008).

In general, the depositional environment of the Cambrian of Murero is interpreted as a low-to-moderate

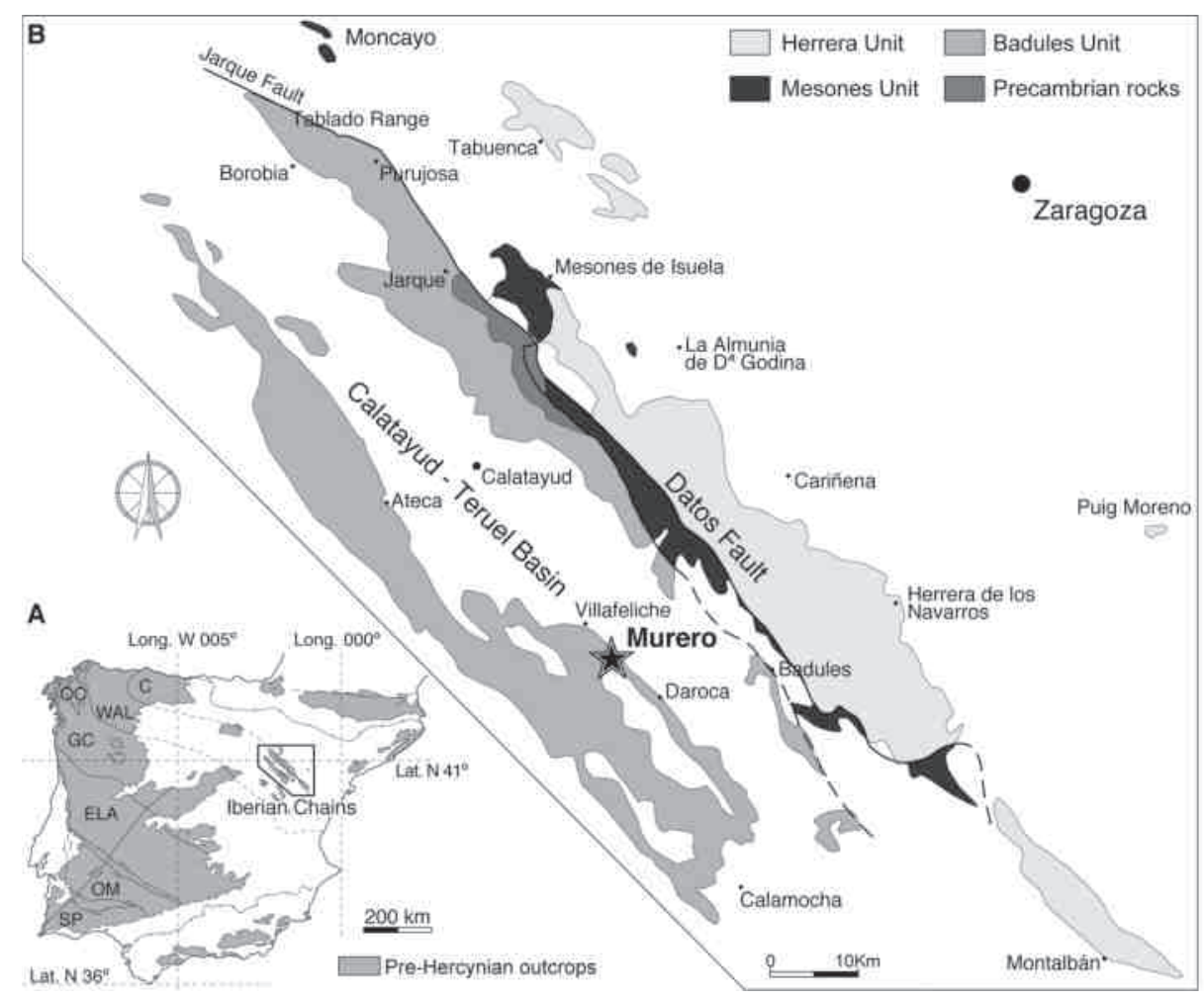

Figure 1. Geographical and geological setting of the study area in Murero. The star indicates the location of the studied section RV1 (modified from Gozalo \& Liñán, 1988; Liñán et al., 2008). 
energy, open sublittoral (infralittoral) shelf located at a subtropical latitude.

The fossil specimen described herein was found at the base of level 15 of section RV1, corresponding to the middle part of the Murero Formation. The fossil assemblage associated to Naraoia sp. is composed of the following taxa: 1) the trilobites Peronopsis acadica, Diplagnostus planicauda, Eccaparadoxides sequeriosi, E. rouvillei, Pardailhania hispida, P. multispinosa, Conocoryphe (Parabailiella) languedocensis, C. (C.) heberti, Ctenocephalus (Hartella) antiquus and Agraulos longicephalus (see Liñán \& Gozalo, 1986; Liñán et al., 2008), and 2) the brahiopods Redlichiella cf. bohemica and Dyctionina radioplicata (Liñán \& Mergl, 2001). This fossil assemblage belongs to the Pardailhania multispinosa Biozone of the middle Caesaraugustan regional Stage, which is correlated with the Drumian Stage (Gozalo et al., 2011).

\section{SYSTEMATIC PALAEONTOLOGY}

Order NEKTASPIDA Raymond, 1920

Family Naraoiidae Walcott, 1912

Genus Naraoia Walcott, 1912

Type species Naraoia compacta Walcott, 1912, by original designation.
Other species. Naraoia spinifer Walcot, 1931; N. halia Simonetta \& Delle Cave, 1975; N. spinosa Zhang \& Hou, 1985; N. bertensis Caron et al., 2004; N. taijiangensis Peng, Zhao \& Sun, 2012.

\section{Naraoia $\mathrm{sp}$}

(Fig. 2)

Material. One incomplete posterior shield preserved as internal mould. It is deposited at the Collection of Type Fossils of the Museo de Ciencias Naturales de la Universidad de Zaragoza (Canudo, 2017) under repository MPZ-2018/29. Morphological terms used in this description are after Zhang et al. (2007).

Description. Slightly distorted posterior shield, broken and incomplete on its posterior area. Its outline is rounded, and it shows a doublure or narrow band around the margin. The surface is slightly convex, gradually flattening laterally and divided longitudinally by a convex axial lobe. The anterior part is located in a lower plane with respect to the majority of the surface and, probably, it represents the overlapping portion between both shields (see Whittington, 1977, p. 420). The axis is raised as a convex ridge along its length, which is highlighted by two straight lateral furrows tapering backward; the axis is also narrow, its width being less than one-fourth of the posterior shield width. The anterior part of the posterior shield shows a branching pattern of gut caeca, with seven transverse branches which
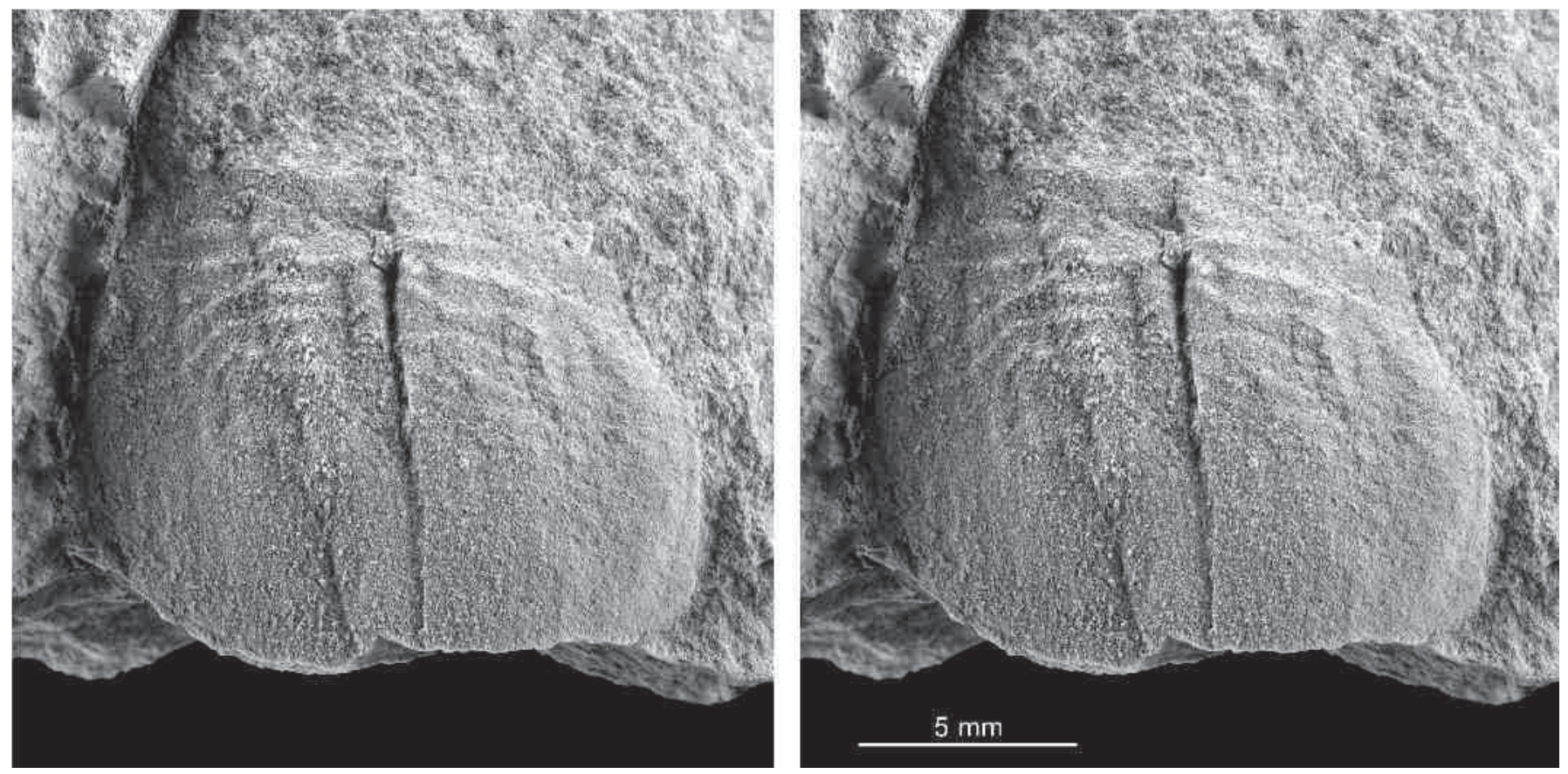

Figure 2. Stereopair pictures of Naraoia sp. Internal mould of posterior shield. Rambla de Valdemiedes 1 section, Level 15. Specimen MPZ 2018/29. 
fade away in the lateral area of the shield. The caeca fade in the posterior part of the posterior shield too.

The maximum transverse width of the specimen is $14.5 \mathrm{~mm}$, while the minimum sagittal length is $11.2 \mathrm{~mm}$, because the posterior part is broken; the possible sagittal length range from 13 to $15 \mathrm{~mm}$. This size indicates that the specimen was an adult (see Zhang et al., 2007).

Remarks. Naraoiid arthropods are clearly defined as nektaspids with the dorsal exoskeleton divided by a single articulation into an anterior and a posterior shield (Zhang et al., 2007, p. 19). The anterior portion of the rounded posterior shield studied herein is interpreted as the overlap portion between both shields; thus our specimen is identified as belonging to the family Naraoiidae. Only two genera are known in the family, namely Naraoia Walcott, 1912, and Misszhouia Chen, Edgecombe \& Ramsköld, 1997. The main character of the latter is the elongated posterior shield (Zhang et al., 2007, p. 31). Thus, in conclusion, we classify the Spanish specimen as Naraoia.

The morphology of the study specimen of Naraoia sp. is close to Naraoia compacta Walcott, 1912 and the morph B of Naraoia spinosa Zhang \& Hou, 1985. Zhang et al. (2007, p. 19) commented that the outline of morph B of $N$. spinosa is similar to that of $N$. compacta, and that the difference lies in the shape of anterior shield. Figure 3 shows a graph of measurements of posterior shield of $N$. compacta and N. spinosa, redrawn, respectively, from Whittington (1977, fig. 2.d) and Zhang et al. (2007, fig. 17.2), and the Naraoia specimen from Murero. The position of the Spanish specimen is, more or less, in the

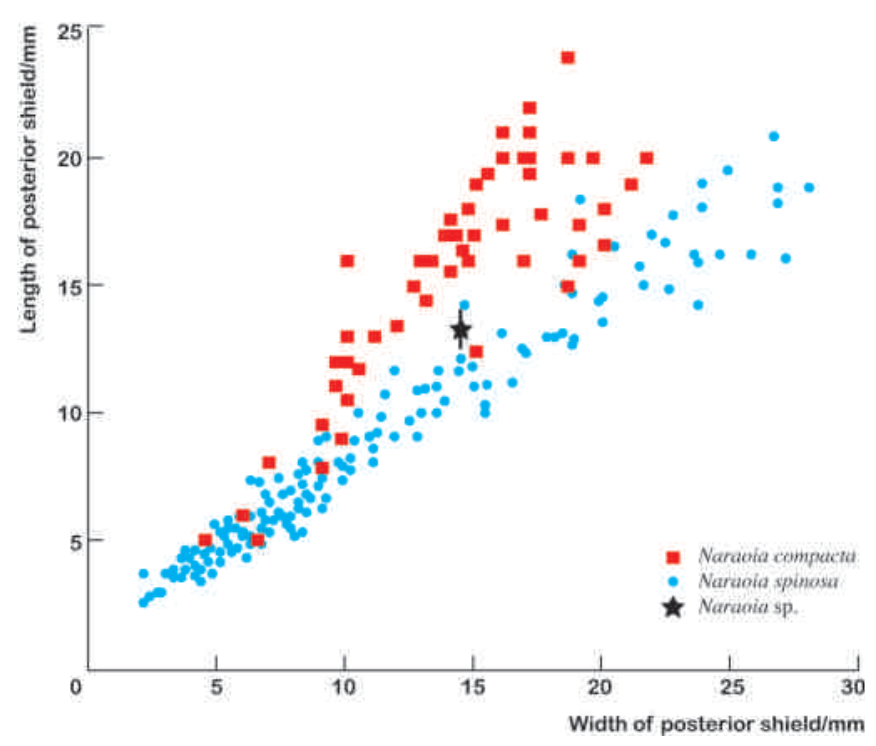

Figure 3. Graphs of measurements, in millimetres, of posterior shield of Naraoia compacta Walcott, 1912 (sensu Whittington, 1977, fig. 2.d), Naraoia spinosa Zhang \& Hou, 1985 (sensu Zhang et al., 2007, fig. 17.2) and Naraoia sp. from Murero. middle of both species distribution. Thus, and also because of the lack of the anterior shield, we prefer to classify the specimen in open nomenclature.

Naraoia sp. differs mostly from $N$. spinifer Walcott, 1931 and morph A of $N$. spinosa Zhang \& Hou, 1985 in that it has no marginal spines in the posterior shield. Naraoia halia Simonetta \& Delle Cave, 1975 has a posterior shield, with an almost straight anterior margin. Finally, Naraoia bertiensis Caron et al., 2004, from the late Silurian, does not have a marked axis in the posterior shield.

Previously, Naraoia sp. had been cited in South Australia (Nedin, 1999). This material is now classified as Emucaris, a genus defined by Paterson et al. (2010) showing a more elongated posterior shield and an axis with polygonal ornament on the dorsal surface, some features that are not present in the Murero specimen.

Occurrence. Base of level 15 of the rambla de Valdemiedes-1 section (RV1/15; Liñán \& Gozalo, 1986, fig. 9), middle part of the Murero Formation, Pardailhania mulstispinosa Biozone (middle Caesaraugustan regional Stage); Drumian Stage in the standard chronostratigraphy.

\section{ACKNOWLEDGEMENTS}

Thanks to Isabel Rábano (IGME) and Miguel Arbizu (Universidad de Oviedo) for their constructive comments. We also want to give our thanks to Ms Isabel Pérez Urresti who assisted us with the figures and photographs. The authors want to acknowledge professors M. ${ }^{a}$ Luisa Martínez Chacón and Luis Carlos Sánchez de Posada for their palaeontological work in the Palaeozoic of Spain and their essential role in the development of the Sociedad Española de Paleontología.

\section{REFERENCES}

Canudo, J.I. 2017. The collection of type fossils of the Natural Science Museum of the University of Zaragoza (Spain). Geoheritage; doi:10.1007/s12371-017-0228-1.

Caron, J.-B., Rudkin, D.M. \& Milliken, S. 2004. A new late Silurian (Pridolian) naraoiid (Euarthropoda: Nektaspida) from the Bertie Formation of Southern Ontario, Canada - Delayed fallout from the Cambrian Explosion. Journal of Paleontology, 78, 1138-1145; doi:10.1666/00223360(2004)078<1138:ANLSPN>2.0.CO;2

Chen, J.-Y., Edgecombe, G.D. \& Ramsköld, L. 1997. Morphological and ecological disparity in naraoiids (Arthropoda) from the Early Cambrian Chengjiang fauna, China. Records of the Australian Museum, 49, 1-24. 
Conway Morris, S. \& Robison, R.A. 1986. Middle Cambrian priapulids and other soft-bodied fossils from Utah and Spain. The University of Kansas Paleontological Contributions, Paper, 117, 1-22.

Gámez Vintaned, J.A. 1995. Nuevo hallazgo de un anélido (?) paleoscolécido en el Cámbrico Medio de Murero (Cadena Ibérica Occidental, NE de España). In: Memorias de las IV Jornadas Aragonesas de Paleontología: "La expansión de la vida en el Cámbrico" Libro homenaje al Prof. Klaus Sdzuy (eds. Gámez Vintaned, J.A. \& Liñán, E.). Klaus Sdzuy. Institución "Fernando el Católico", Zaragoza, 205-218.

Gámez Vintaned, J.A. \& Mayoral Alfaro, E. 1992. Primeras aportaciones a la Paleoicnología del Grupo Murero (Cámbrico Inferior-Medio) en Murero (Provincia de Zaragoza. Cadena Ibérica Occidental). Geogaceta, 12, 100-102.

Gámez Vintaned, J.A. \& Mayoral, E. 1995. Paleoicnología del Grupo Mesones (Cámbrico Inferior-Medio) en Murero (Cadena Ibérica Occidental, NE de España). In: Memorias de las IV Jornadas Aragonesas de Paleontología: "La expansión de la vida en el Cámbrico” Libro homenaje al Prof. Klaus Sdzuy (eds. Gámez Vintaned, J.A. \& Liñán, E.). Institución "Fernando el Católico", Zaragoza, 219-252.

Gámez Vintaned, J.A., Liñán, E. \& Zhuravlev, A.Yu. 2011. A new early cambrian lobopod-bearing animal (Murero, Spain) and the problem of the ecdysozoan early diversification. In: Evolutionary Biology - Concepts, Biodiversity, Macroevolution and Genome Evolution (ed. Pontarott, P.I.), Springer-Verlag, 193-219.

García-Bellido, D.C., Gozalo, R., Chirivella Martorell, J.B. \& Liñán, E. 2007. The Demosponge genus Leptomitus and a new species from the Middle Cambrian of Spain. Palaeontology, 50, 467-478; doi:10.1111/j.14754983.2007.00635.x.

García-Bellido, D.C., Dies Álvarez, M.E., Gámez Vintaned, J.A., Liñán, E. \& Gozalo, R. 2011. First report of Crumillospongia (Demospongea) from the Cambrian of Europe (Murero biota, Spain). Bulletin of Geosciences, 86, 641-650; doi:10.3140/bull.geosci.1253.

Gozalo, R. \& Liñán, E. 1988. Los materiales hercínicos de la Cordillera Ibérica en el contexto del Macizo Ibérico. Estudios geológicos, 44, 399-404; doi:10.3989/ egeol.88445-6556.

Gozalo, R., Liñán, E. \& Álvaro, J. 1993. Bioestratigrafía del Cámbrico Medio de Villafeliche (Prov. Zaragoza, España). Revista Española de Paleontología, $\mathrm{n}^{\mathrm{o}}$ extraordinario, 49-57.

Gozalo, R., Dies, M.E. \& Chirivella, J.B. 2004. New occurrence of the family Hipponicharionidae (Bradoriida, Arthropoda), in the lower and middle Cambrian of the Cadenas Ibéricas, Spain. Geobios, 37, 191-197; doi:10.1016/j.geobios.2003.04.001.

Gozalo, R., Chirivella, J.B., Esteve, J. \& Liñán, E. 2011. Correlation between the base of Drumian Stage and the base of middle Caesaraugusan Stage in the Iberian Chains (NE Spain). Bulletin of Geosciences, 86, 545-554; doi:10.3140/bull.geosci.1254.
Hou X-G., Aldridge, R.J., Bergström, J., Siveter, David J., Siveter, Derek J. \& Feng X.-H. 2004. The Cambrian Fossils of Chengjiang, China. The Flowering of Early Animal Life. Blackwell Publishing, 233 p.; doi:10.1002/9781118896372.

Liñán, E. \& Gozalo, R. 1986. Trilobites del Cámbrico Inferior y Medio de Murero (Cordillera Ibérica). Memorias del Museo Paleontológico de la Universidad de Zaragoza, 2, 1-104.

Liñán, E. \& Mergl, M. 2001. Lower and Middle Cambrian brachiopods from the Iberian Chains and Sierra Morena (Spain). Revista Española de Paleontología, 16, 317-337.

Liñán, E., Villas, E., Gámez Vintaned, J.A., Álvaro, J.J., Gozalo, R., Palacios, T. \& Sdzuy, K. 1996. Síntesis paleontológica del Cámbrico y Ordovícico del Sistema Ibérico (Cadenas Ibéricas y Cadenas Hespéricas). Revista Española de Paleontología, $\mathrm{n}^{\mathrm{o}}$ extraordinario, 21-32.

Liñán, E., Gozalo, R., Dies Álvarez, M.E., Gámez Vintaned, J.A., Mayoral, E., Chirivella Martorell, J.B., Esteve, J., Zamora, S., Zhuravlev, A.Yu. \& Andrés, J.A. 2008. Fourth International Trilobite Conference Trilo 08. Toledo, Spain, 2008. Post-Conference Field Trip. Lower and Middle Cambrian trilobites of selected localities in Cadenas Ibéricas (NE Spain). Universidad de Zaragoza, 52 p.

Liñán, E., Gámez Vintaned, J.A., Dies Álvarez, M.E., Chirivella Martorell, J.B., Mayoral, E., Zhuravlev, A.Yu. \& Gozalo, R. 2012. 150 years of the discovery of the Cambrian Lagerstätte of Murero (Cadenas Ibéricas, NE Spain). Journal of Guizhou University, 29 (supp. 1), 28-34.

Nedin, C. 1999. Anomalocaris predation on nonmineralized and mineralized trilobites. Geology, 27, 987-990; doi:10.1130/0091-7613(1999)027<0987:APONAM $>2.3$ $\mathrm{CO} ; 2$.

Paterson, J.R., Edgecombe, G.D., García-Bellido, D.C., Jago, J.B. \& Gehling, J.G. 2010. Nektaspid arthropods from the lower Cambrian Emu Bay Shale lagerstätte, South Australia, with a reassessment of lamellipedian relationships. Palaeontology, 53, 277-402; doi:10.1111/ j.1475-4983.2010.00932.x.

Peng, J., Zhao, Y.L. \& Sun, H. 2012. Discovery and significance of Naraoia from the Qiandongian (lower Cambrian) Balang Formation, Eastern Guizhou, South China. Bulletin of Geosciences, 87, 143-150; doi:10.3140/ bull.geosci.1231.

Raymond, P.E. 1920. The Appendages, Anatomy, and Relationships of Trilobites. Memoirs of the Connecticut Academy of Arts and Sciences, 7, 1-169.

Robison, R.A. 1984. New occurrences of the unusual trilobite Naraoia from the Cambrian of Idaho and Utah. The University of Kansas Paleontological Contributions, Paper, 112, 1-8.

Sdzuy, K. 1972. Das Kambrium der acadobaltischen Faunenprovinz. Zentralblatt für Geologie und Paläontologie, Teil II, 1972(1-2), 1-91.

Sdzuy, K., Liñán, E. \& Gozalo, R. 1999. The Leonian Stage (early Middle Cambrian): a unit for Cambrian correlation in the Mediterranean subprovince. Geological Magazine, 136, 39-48; doi:10.1017/S0016756899002241. 
Simonetta, A.M. \& Delle Cave, L. 1975. The Cambrian non-trilobite arthropods from the Burgess Shale of British Columbia. A study of their comparative morphology, taxonomy and evolutionary significance. Palaeontographica Italica, 69, 1-37.

Walcott, C.D. 1912. Cambrian geology and paleontology II. No. 6. Middle Cambrian Branchiopoda, Malacostraca, Trilobita, and Merostomata. Smithsonian Miscellaneous Collections, 57, 145-229.

Walcott, C.D. 1931. Addenda to descriptions of Burgess Shale Fossils (whit explanatory notes by Charles E. Resser). Smithsonian Miscellaneous Collections, 85, 1-46.

Whittington, H.B. 1977. The Middle Cambrian Trilobite Naraoia, Burgess Shale, Brithish Columbia. Philosophical Transactions of the Royal Society London, Series B, 280, 409-443; doi:10.1098/rstb.1977.0117.

Zamora, S. 2011. Equinodermos del Cámbrico de España: situación actual de las investigaciones y perspectivas futuras. Estudios geológicos, 67, 59-81; doi:10.3989/ egeol.40240.121.

Zhang, W.-T. \& Hou, X.-G. 1985. Preliminary notes on the occurrence of the unusual trilobite Naraoia in Asia. Acta Palaeontologica Sinica, 24, 591-595.

Zhang, X.-L., Shu, D.-G. \& Erwin, D.H. 2007. Cambrian naraoiids (Arthropoda): morphology, ontogeny, systematics, and evolutionary relationships. Journal of Paleontology, 81 (supplement to No. 5), 52 p.; doi: 10.1666/06-082.1.

Zhao, Y.L., Zhu, M.Y., Babcock, L.E., Yuan, J.L., Parsley, R.L., Peng, J., Yang, X.L. \& Wang, Y. 2005. Kaili Biota: A taphonomic window on diversification of metazoans from the basal Middle Cambrian, Guizhou, China. Acta Geologica Sinica, 79, 751-765; doi:10.1111/j.1755-6724.2005.tb00928.x.

Zhuravlev, A.Yu., Gámez Vintaned, J.A. \& Liñán, E. 2011. The Palaeoscolecida and the evolution of the Ecdysozoa. Palaeontographica Canadiana, 31, 177-204. 